\title{
Difficulties in the Incorporation of Augmented Reality in University Education: Visions from the Experts
}

\author{
Julio Barroso-Osuna ${ }^{1} \oplus$, Juan Jesús Gutiérrez-Castillo ${ }^{1} \odot, M^{a}{ }^{2}$ el Carmen Llorente-Cejudo ${ }^{1} \odot$ and
} Rubicelia Valencia Ortiz²

\author{
${ }^{1}$ Departamento de Didáctica y Organización Educativa, University of Seville, Spain \\ ${ }^{2}$ Latin American Institute for Educational Communication (ILCE), Mexico
}

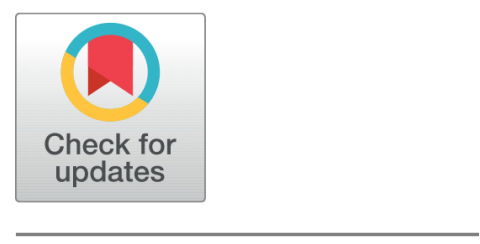

Received 13-02-2019

Revised 28-02-2019

Accepted 05-04-2019

Published 15/07/2019

\section{Corresponding Author}

Julio Barroso-Osuna,

jbarroso@us.es

Facultad de Ciencias de la Educación, Departamento de Didáctica y Organización

Educativa, C/ Pirotecnia s/n, 41013, Seville, Spain

DOI https://doi.org/10.7821/

naer.2019.7.409

Pages: 126-141

Funding: Ministry of Economy and Competitiveness of the

Government of Spain

(EDU2014-57446-P)

Distributed under

Creative Commons CC BY 4.0

Copyright: (C) NAER Journal of New Approaches in Educational Research 2019

\section{ABSTRACT}

"Augmented reality" (AR) is presented as technology that harmonizes, in real time and with user collaboration, digital information with physical information through different technological supports. Such are AR possibilities, that when it is incorporated into teaching, students show high satisfaction rates and positive attitudes for its use, but at the same time, a series of limitations and obstacles can be noticed. As an attempt to investigate the technical, curricular and organizational difficulties of $\mathrm{AR}$ incorporation in training contexts, an instrument "AR obstacle questionnaire" (CORA) was designed, which in turn was administered to a total of 264 subject experts for validation through the Delphi method, subsequently applying the " $\mathrm{K}$ coefficient" ( $\mathrm{K}=\frac{1}{2} \mathrm{Kc}$ (knowledge coefficient) + Ka (argumentation coefficient)), selecting those experts who obtained $a \geq 0,8$ score in the coefficient. Among the results obtained in the study we manage to point out the main obstacles involving AR implementation into university education: the lack of teacher training and improvement, the few educational experiences found, lack of conceptual foundation, limited educational research and lack of institutional support.

Keywords AUGMENTED REALITY, HIGHER EDUCATION, EMERGING TECHNOLOGIES, INFORMATION AND COMMUNICATION TECHNOLOGIES, DIGITAL COMPETENCES

\section{AUGMENTED REALITY APPLIED TO UNIVERSITY EDUCATION}

The insertion that information and communication technologies (ICTs) have recently had into educational actions and institutions, is of a magnitude that had not previously occurred, this being a direct consequence of digitalization, transmedia, the exponential growth of technologies, the penetration of web 2.0 and the significance that ICTs hold in knowledge society. Technologies such as "learning analytics", "gamification", "serious video games", or "robotics", are rapidly being incorporated into teaching as the "Horizon Reports" prepared by "The New Media Consortium" ${ }^{1}$ point out, or the EduTrends reports produced by

\footnotetext{
${ }^{1}$ https : //www.nmc.org/nmc-horizon/
}

\section{OPEN ACCESS}


the "Observatory of Educational Innovation" of Tecnológico de Monterrey ${ }^{2}$. Augmented Reality applied to university education.

One such technology is "augmented reality" (AR), which is a type of technology that harmonizes in real time, and with the collaboration of the user, digital information with physical information through different technological supports, being those which are the most common mobile devices such as smartphones and tablets. (Cabero-Almenara, Fernández, \& Marín, 2017; Cabero-Almenara \& García, 2016). It is precisely the type of device typically used, which facilitates its incorporation into university education since they are owned by the vast majority of students, and in addition, they tend to hold significant attitudes towards them (Lagunes-Domínguez, Torres-Gastelú, Angulo-Armenta, \& MartínezOlea, 2017; Seifert, Hervás, \& Toledo, 2019).

In comparison to other technologies, it holds a series of specific characteristics:

- Being of mixed reality, enabling the enrichment or complementing the information of reality with digital information.

- Integration occurs in real time and in a cohesive manner.

- Facilitates the unification of different resources: text, websites, video clip, audio, and 3D.

- It is interactive.

- In the creation of content, intervention from a person is necessary.

In regards to its impact on education, and although the research carried out is limited, an aspect that is possibly one of the biggest issues relates to its incorporation into teaching, studies like the one conducted by Joo, García-Bermejo, and Martinez-Abad (2016) give us clues ensuring that the AR objects that we design can be used with some guarantee of success. With this line of thought we can say that objects, in terms of content, have to be short and direct, lasting no longer than 5 minutes, they must consider the different capacities of the students, the activities must be presented with an intuitive interface that allows the rapid correction of errors and with a constructivist character, in which the participation and the exchange between the students is encouraged, presentation of objects with multimedia character, with clear practical orientation and finally, but not any less importantly, it is advised that the AR objects adapt to the characteristics of the devices in which they will be viewed.

And also through its use, the information of physical reality where it is integrated is enriched or altered. The possibilities of incorporation into training are diverse: a) nonsignificant information for understanding of a phenomenon; b) enriches the information of the reality to facilitate its understanding; c) provides different points of view of an object, choosing the person the moment and perspective of observation; d) enhances ubiquitous learning; e) creates safe laboratories and/or simulators for students; f) enriches printed documents with additional information on different media; g) allows the student to visualize a phenomenon from multiple perspectives thus enhancing spatial intelligence; $h$ ) students

\footnotetext{
${ }^{2}$ https://observatorio.itesm.mx/redutrends/
} 
can be actors producing these objects, i) allows the exposure of temporal phenomena and especially heterogeneous, and j) contextualizes information (Fonseca, Redondo, \& Valls, 2016; Han, Jo, Hyun, \& So, 2015; Jamali, Fairuz, undefined K., \& Oskam, 2015; Maquilón, Mirete, \& Avilés, 2017; Santos et al., 2016).

Possibilities that when applied to teaching, show students to have high levels of satisfaction and positive attitudes for their use (Akçayır \& Akçayır, 2017; Y. Hsu, Lin, \& Yang, 2017; Joo, Martínez, \& García-Bermejo, 2017), are motivated towards these educational actions (Cheng, 2017; Garay, Tejada, \& Maiz, 2017) and improves academic performance (Lu \& Liu, 2015; Tekedere \& Göker, 2016; Yilmaz \& Goktas, 2017).

It should be indicated that it has been incorporated into different university disciplines: engineering and architecture (Odeh, Shanab, \& Anabtawi, 2015), mathematicsgeometry (Coimbra, Cardoso, \& Mateus, 2015), languages (T. C. Hsu, 2017), biology (Fracchia, Alonso, \& Martins, 2015), geography (Tsai, Liu, \& Yau, 2013), medicine (Barroso \& Cabero-Almenara, 2016), education sciences (Garay et al., 2017; Martínez \& Fernández, 2018), or engineering (Ibáñez \& Delgado-Kloos, 2018).

\section{RESEARCH}

\subsection{Research Objectives}

This research was conducted as a part of a R \& D + I project called "Augmented reality to increase training. Design, Production and Evaluation of augmented reality programs for university education", funded by the Ministry of Economy and Competitiveness of the Government of Spain, the objective being sought after in the present work is: "To investigate the technical, curricular and organizational challenges that AR application may be faced with in university education".

To this end, different actions were developed, ranging from the review of literature, the construction of a specific instrument on limitations that were exposed in the scientific literature that could hinder the incorporation of AR into teaching, the selection of a series of experts, and the assessment by the experts on the significance of the limitations pointed out in the scientific literature.

\subsection{Research Strategy}

One of the strategies used in educational research is the so-called "expert judgment", with a "Delphi" modality application, which is one of the most used methods to configure the content validity of a scale or a questionnaire (López-Gómez, 2018; Pérez-Pérez, Gómez, \& Sebastián, 2018). As Gil-Gómez and Pascual-Ezama (2012) point out: "the Delphi methodology is a technique framed within the methods of experts that is used to obtain the most consensual opinion possible from a group of people, considered experts, in relation to a certain research objective". (p. 1011)

Methodology that is commonly used for different aspects: analyzing the validity of the items in a questionnaire, studying the accuracy of meaning of terms, evaluating educational material, or identifying solutions to a problem (Barroso, Cabero, \& Llorente, 2015; Escobar 
\& Cuervo, 2008; Gil-Gómez \& Pascual-Ezama, 2012; Hernández, Fernández, \& Baptista, 2010).

Its application is carried out from different perspectives: individual aggregation of the experts, Delphi method, nominal group technique, and consensus method (Cabero \& Barroso, 2013). Here we are using a combination of the first two, in what is called a "partially modified Delphi" in which the information is obtained individually without the experts being in contact.

One of the problems for its use is how to select the experts that will participate in the investigation. And for this, different procedures are used, ranging from the analysis of their curriculum, to the use of procedures such as the "coefficient of expert competence" (Coefficient K) (Blasco, Padrón, \& Mengual, 2010; García \& Fernández, 2008); procedure that has been used recently by different authors in different investigations: Cabero and Barroso (2013), Llorente and Journal of New Approaches in Educational Research (2013), Zartha, Montes, Toro, and Villada (2014), and Mengual-Andrés, Roig-Vila, and Blasco (2016).

In this study both procedures were used; firstly, the "AR obstacle questionnaire was sent out" (CORA), which we will present later, to different experts selected using the following criteria: having experience in the field of educational technology and the use of ICT in the field of education, having experience in the field of $A R$, belonging to the research team of the RAFODIUN project, and being from different Spanish and Latin American universities. At the same time, a link was placed in the "RAFODIUN Virtual Community" developed in Google+ for the project so that it could be completed voluntarily by people who wanted it.

As regards to the number of experts needed to carry out the Delphi study, there is no definitive rule, and as López-Gómez (2018, p.24) points out: “[...] estimating the optimal number of the panel requires of a contingent approach, that takes into account the nature of the research and the objectives to be achieved, the geographic scope and the resources available to the researcher". Our research, based on these arguments, makes an extensive selection of them, emphasized by the coefficient of Expert competence in their final selection.

The number of "experts" who initially completed the CORA was 264, and with these we apply the "K coefficient" ( $\mathrm{K}=\frac{1}{2} \mathrm{Kc}$ (knowledge coefficient) + Ka (argumentation coefficient)), which assumes that the expert assesses on a scale from 0 to 10 the degree of knowledge they have on the subject (Kc) and argue according to a table of value where you have acquired the training, and which is scored according to the values shown in Table 1.

Table 1 Questions and scores for obtaining the Ka of the "Expert Competency Coefficient".

\begin{tabular}{llll} 
& High & Medium & Low \\
\hline Theoretical analysis carried out by you & 0,3 & 0,2 & 0,1 \\
Your experience gained from your practical activity & 0,5 & 0,4 & 0,2 \\
Study the work on the subject, by Spanish authors & 0,05 & 0,05 & 0,05 \\
Study the work on the subject, by foreign authors & 0,05 & 0,05 & 0,05 \\
Your own knowledge about the status of the problem abroad & 0,05 & 0,05 & 0,05 \\
Your intuition about the subject & 0,05 & 0,05 & 0,05 \\
\hline
\end{tabular}


In general terms, it is suggested (Cabero \& Barroso, 2013; Llorente \& Journal of New Approaches in Educational Research, 2013; Mengual-Andrés et al., 2016), that those experts who obtain a score $\geq$ a 0.8 in the coefficient be the ones selected. In our case, this value was reached by 208 subjects, who became those that were considered for the study, having, therefore, rejected 56 of those who completed the questionnaire.

In regards to the characteristics of these 208 experts, it is indicated that $80.77 \%$ ( $f=168$ ) held a doctorate degree, $11.54 \%(f=24)$ a masters degree, $3.88 \%(f=8)$ a bachelors degree, and $8(\mathrm{f}=3.88 \%)$ had other studies. Of them the great majority $(\mathrm{f}=188,90.39 \%)$ worked in a university center, while the remainder worked in non-university centers $(f=8,3.88 \%)$, a company related to training $(\mathrm{f}=8,3,88 \%$ ), a company related to technological production ( $\mathrm{f}=2,0.96 \%)$, and 2 indicated 'other' $(0.966 \%)$. Its basic activity was teaching ( $\mathrm{f}=148$, $71.15 \%)$, although another large percentage worked both in teaching and in the technical part $(\mathrm{f}=42,20.19 \%)$, the rest worked in technical aspects $(\mathrm{f}=8,3.88 \%)$ and in management $(\mathrm{f}=8,3.88 \%)$.

It was indicated that $97.11 \%(\mathrm{f}=2012)$ had taught subjects related to Educational Technology or ICT applied to training and that they had participated in some research on ICT, virtual training or AR. At the same time, 93.27\% $(\mathrm{f}=194)$ had published on these aspects.

\subsection{Information collection instrument}

The instrument for collecting information on the obstacles to the incorporation of AR in training was a questionnaire with a Likert type format, with 7 response options (from $0=$ nothing significant to 6 = very significant). For its construction we follow three stages: a) telephone survey to a series of "experts" in Educational Technology and AR on the most significant obstacles they would face in the implementation of the AR in university education, b) review of scientific articles on AR published in database journals "Web of Science", "Scopus", and in the "Seal of Quality of Spanish Scientific Journals", and c) obtaining the reliability index.

The first phase consisted of the telephone call to different teachers of Educational Technology of different Spanish Universities, to which the following question was asked: what do you think are the most significant obstacles that can hinder the incorporation of AR in university teaching? In total twenty-five calls were made.

Simultaneously, a review of the AR literature was carried out to identify problematic situations that, according to different authors, presented the main drawbacks and difficulties that can be encountered in the incorporation of AR to teaching. The results obtained are shown in Table 2.

The gathering of the data obtained by both procedures allowed for the identification of a series of dimensions:

- Educational futility (EF)

- Difficulty using technology (DUT)

- Missing student training (MST)

- Student attitude/belief for incorporation (SAI) 
Table 2 Dimensions identified in different works

\begin{tabular}{|c|c|}
\hline Dimensions & Authors \\
\hline Student training & Durall et al. (2012) and Liu and Tsai (2013) \\
\hline Few educational experiences, & $\begin{array}{l}\text { Johnson et al. (2012), Cuendet et al. (2013), Wojciechowski and Cellary (2013), Bower et al. } \\
\text { (2014), Radu (2014), Cabero-Almenara and García (2016) }\end{array}$ \\
\hline Few investigations & $\begin{array}{l}\text { Serio et al. (2013), Lin et al. (2013), Chen and Tsai (2012), Wu et al. (2013), X. Wang et al. } \\
\text { (2013), Bacca et al. (2014), and Saidin et al. (2015) }\end{array}$ \\
\hline $\begin{array}{l}\text { Difficulty creating interactive content and } \\
\text { few educational materials }\end{array}$ & $\begin{array}{l}\text { Carracedo and Méndez (2012), Cabero-Almenara and García (2016) and Akçayır and Akçayır } \\
\text { (2017) }\end{array}$ \\
\hline The technology is not yet very precise & Telefónica (2011), O’Shea et al. (2012) and Saidin et al. (2015) \\
\hline Teacher training & $\begin{array}{l}\text { Durall et al. (2012), Bower et al. (2014), Billinghurst and Duenser (2012) and Cabero-Almenara } \\
\text { and García (2016) }\end{array}$ \\
\hline It is limited to advanced devices & Telefónica (2011) and Y. Wang (2017) \\
\hline Search for active methodologies & Durall et al. (2012) \\
\hline Diversity of technologies & Fombona et al. (2012) \\
\hline Teaching attitude & Wu et al. (2013) and Alkhattabi (2017) \\
\hline $\begin{array}{l}\text { Unflexible curriculum and instructional } \\
\text { design }\end{array}$ & Durall et al. (2012), Cuendet et al. (2013) and Wu et al. (2013) \\
\hline Cognitive overload of students & Dunleavy et al. (2010), Wu et al. (2013), Akçayır and Akçayır (2017) and Y. Wang (2017) \\
\hline Lack of conceptual references & Rasimah et al. (2011) and Bower et al. (2014) \\
\hline It is not easy to manage & J. L. Hsu and Huang (2011), Saidin et al. (2015) and Y. Wang (2017) \\
\hline Economic factors & Cabero-Almenara and García (2016) and Y. Wang (2017) \\
\hline
\end{tabular}

- Teacher attitude/belief for incorporation (TAI)

- Lack of educational experience (LEE)

- Lack of conceptual foundation (LCF)

- Lack of teacher training (LTC)

- Technological/economic

- Lack of educational research (LER)

- Institutional difficulty / lack of institutional support (ID)

- Characteristics educational curriculum (CEC)

Around these we built the CORA, which brought about a first version that was reviewed by members of the research team RAFODIUN, leaving the final version consisting of four major blocks: characterization of the expert, questions for the analysis of expert competence, assessment of the influence of a series of obstacles by the experts ( 41 items) and an open question to explain if they thought there might be another obstacle not indicated in the items. The questionnaire was applied via the web.

In Table 3, the reliability indices obtained are presented both for the overall nature of the instrument and for each of the dimensions. Indicating that these show high levels of reliability of the instrument to be indicated (Dwyer \& Bernauer, 2014), although in the "Missing student training" and "Attitude/pupils belief for incorporation" dimensions, the values were relatively moderate, possibly due to the fact that these were the dimensions on which we formulated the smallest number of items. It should be noted that in order to identify if the elimination of any item would increase the degree of reliability, we perform the 
item-total correlation, pointing out that the data obtained did not indicate that the elimination of any of them would increase the degree of reliability, hence we made the decision to keep the 41 items.

\begin{tabular}{|c|c|}
\hline Dimension & Cronbach's Alpha \\
\hline Instrument & 0,944 \\
\hline IE (ítems: 11, 18 and 22) & 0,787 \\
\hline DUT (ítems: 4, 13, 14, 15, 16, 26 and 27) & 0,801 \\
\hline FFA (ítems: 31 and 37) & 0,635 \\
\hline ACA (ítems: 19 and 28) & 0,56 \\
\hline ACP (ítems: 20 and 24) & 0,875 \\
\hline FEE (ítems: 1, 3 and 21) & 0,661 \\
\hline FFC (ítems: 2, 9 and 25) & 0,65 \\
\hline FFP (ítems: 5, 30 and 32) & 0,788 \\
\hline PTE (ítems: 7, 6, 10, 12, 17, 23 and 29) & 0,787 \\
\hline FIE (ítems: 8,33 and 39) & 0,812 \\
\hline DI (ítems: 33, 34 and 35) & 0,836 \\
\hline CCE (ítems: 38,40 and 41) & 0,904 \\
\hline
\end{tabular}

The instrument was applied via the Internet, and the study was carried out at the end of 2017.

\section{RESULTS}

We will begin our analysis by presenting the average scores and standard deviations reached in the different items that constituted the instrument (Table 4).

The ten items that obtained lower than average score, and thus indicating to be obstacles of few or no significance, were the following:

- It can only be used by adults and at higher levels of education (1.31).

- It only serves to distract, not for students to learn and acquire knowledge (1.33).

- Its use can only mobilize traditional methodologies and nothing innovative (1.39).

- Students feel bored and confused when they are immersed in situations of using learning objects in AR (1.40).

- It cannot be used in all disciplines (1.42).

- The attitude shown by students towards these technologies is not positive for its incorporation into teaching (1.56).

- Students believe that AR is not a significant technology for learning (1.66).

- Students are not trained for its use (1.82).

- These are very rigid systems that do not allow their adoption by the teacher in their class context (1.95) 
Table 4 Obstacles for the incorporation of RA in university training contexts

Ítem

M SD

1) There are more technological developments than educational practices and experiences

$4,49 \quad 1,52$

2) Its novelty prevents the lack of conceptual and theoretical reflection for its incorporation into educational practice

$3,87 \quad 1,48$

3) The incorporation experiences carried out are more specific actions, than planned and continued actions for their educational adoption

4) Lack of educational materials for its incorporation into teaching

$4,54 \quad 1,49$

5) The lack of teacher training for its use, and especially for its application in innovative teaching strategies

$5,07 \quad 1,27$

6) The technological devices that are used for interaction have different operating systems, which calls for the realization of different

versions of objects, and this makes it difficult to incorporate them into teachin

7) The difficulty and cognitive disorientation that supposes for some students, interacting in a context formed by the mixture of the real and virtual

8) The lack of educational research

9) The lack of a theoretical foundation to make decisions regarding its use and incorporation into teaching

10) Expensive equipment is needed for its use

$4,09 \quad 1,57$

$2,96 \quad 1,84$

11) It only serves to distract, not for students to learn and acquire knowledge

$1,33 \quad 1,61$

12) The educational centers do not have the technology for their use

$3,52 \quad 1,84$

13) It is difficult to produce by the teaching staff

14) Objects produced in AR are difficult to use by students

15) It can only be used by adults at higher levels of education

$3,86 \quad 1,56$

$2,08 \quad 1,64$

16) It cannot be used in all disciplines

$1,31 \quad 1,57$

17) For its use, it is necessary to have state-of-the-art technological devices

$1,42 \quad 1,61$

18) Its use can only mobilize traditional methodologies and nothing innovative

$2,621,93$

$1,39 \quad 1,78$

19) The attitude shown by students towards these technologies is not positive for its incorporation into teaching

$1,56 \quad 1,84$

20) The attitude shown by teachers towards these technologies is not positive for their incorporation into teaching

$3,43 \quad 1,62$

21) We do not have a volume of "good practices" that indicate how to incorporate it into teaching

$4,14 \quad 1,37$

22) There are very rigid systems that do not allow their adoption by the teacher in their class context

23) Although it has evolved in recent times, its technical operation is imprecise

24) The resistance of teachers to the incorporation of ICT in education

25) The lack of instructional design for incorporation

26) Cognitively overload students because of the diversity of information they can offer

$2,37 \quad 1,54$

$4 \quad 1,57$

$4,11 \quad 1,44$

$2,1 \quad 1,63$

27) Students feel bored and confused when they are immersed in situations of using learning objects in AR

$1,4 \quad 1,58$

28) Students believe that AR is not a significant technology for learning

$1,661,58$

29) Industrial houses that do not decide to establish a technological standard for the use of AR

$3,38 \quad 1,8$

30) The lack of knowledge that teachers have about this technology

$4,7 \quad 1,3$

31) The ignorance that students have of this technology

$3,26 \quad 1,84$

32) Teachers are not trained for its use in teaching

33) There are no educational researches that allow analyzing their educational possibilities

34) The educational institution does not favor the use of ICT in general, and AR in particular

35) In the educational centers, there is no technology for its use

36) No institutional support is received for the incorporation of AR

37) Students are not trained for its use

38) The rigidity of the educational curriculum does not facilitate the incorporation of AR technology

39) There is scarce research on their educational possibilities

40) The educational curriculum is usually not very flexible to make educational technological innovations with the AR 
- Objects produced in AR are difficult to use for students (2.08).

Contrastively, the ten items that obtained the highest average score, and which suggest very significant obstacles for their incorporation were the following:

- The lack of instructional design for incorporation (4.11).

- We do not have a volume of "good practices" that indicate how to incorporate it into teaching (4.14).

- The educational institution does not favor the use of ICT in general, and AR in particular (4.15).

- The lack of educational research (4.37).

- There are more technological developments than educational practices and experiences (4.49).

- Lack of educational materials for its incorporation into teaching (4.54).

- The incorporation experiences carried out are more specific actions, than planned and continued actions for their educational adoption (4.56).

- The lack of knowledge that teachers have about this technology (4.70). Teachers are not trained for its use in education (4.79).

- The lack of teacher training for its use, and above all for its application in innovative teaching strategies (5.07).

With regard to the mena scores and standard deviation reached, both in the overall nature of the instrument and in the different dimensions that make it up, the results are presented in Table 5 .

Table 5 Mean and standard diviation obtained in the dimensions

\begin{tabular}{lll} 
Dimension & M & SD \\
\hline Educational futility (EF) & 1,55 & 1,44 \\
Difficulty using technology (DUT) & 2,39 & 1,13 \\
Missing student training (MST) & 2,54 & 1,53 \\
Student attitude / belief for incorporation (SAI) & 1,61 & 1,45 \\
Teacher attitude / belief for incorporation (TAI) & 3,71 & 1,48 \\
Lack of educational experience (LEE) & 4,4 & 0,97 \\
Lack of conceptual foundation (LCF) & 4,02 & 1,15 \\
Lack of teacher training (LTC) & 4,85 & 1,07 \\
Technological / economic problems (TEP) & 3,1 & 1,17 \\
Lack of educational research (LER) & 3,94 & 1,4 \\
Institutional difficulty / lack of institutional support (ID) & 3,89 & 1,46 \\
Characteristics of educational curriculum (CEC) & 3,27 & 1,64 \\
\hline
\end{tabular}

Five have been the dimensions, to which the experts pointed out that might present the most difficulty:

- Lack of teacher training 
- Lack of educational experience

- Lack of conceptual foundation

- Lack of educational research

- Institutional difficulty / lack of institutional support (3.89)

The low significance attributed to it as being useless material for teaching, should be noted, and that the students could have negative attitudes towards it.

The last question of the questionnaire, intended to gather information about whether there was any obstacle not indicated in the questions previously presented. And the first thing to indicate were the comments referring to the completeness of the list offered, and which can be summarized in the comment offered by one of the experts: "I think that the 41 components considered thoroughly cover a range of possible difficulties".

A group of experts signaled out the lack of resources that were destined in the centers for the use of this technology: "Not enough resources are dedicated to the production of materials with $A R$ " and "The investment of the governments to pay for materials and elements in AR in the education system, thus promoting traditional education".

Some obstacles mentioned could be considered operational, such as: finding the materials in English ("Sometimes the educational material is in English, very important" and "the resources are in another language"); non-existence of materials for all subjects ("sometimes there are no resources for the topics that the teacher needs to work", "there are no materials in the area of educational marketing" or "lack of materials adapted to students with special educational needs"), the diversity of technology ("The diversity of applications and apps for its use sometimes makes it difficult to install several on different devices" or "The incorpo-

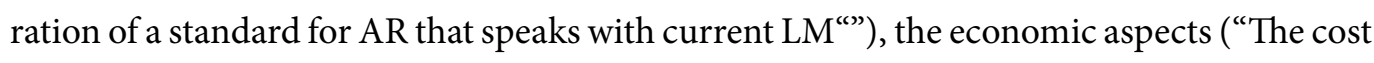
of equipment"), and the lack of support staff for teachers ("The lack of personnel prepared to support the use of AR in teaching is very important").

Other identified obstacles can be framed in the educational type, as can be seen from the following comments: "In general the conservatism of the directors", "A more certain methodological change vision, that incorporates learning objects linked to the RA", or that "It must be integrated into the learning design as a new technological contribution that is neither exclusive nor exclusive".

\section{CONCLUSIONS AND IMPLICATIONS}

It must be stated from the beginning, that the procedure followed both for the selection of experts and in the construction of the information collection instrument, allows us to guarantee the validity of the data obtained.

Our first conclusion, in reference to the objective being perused at the beginning of the work on "Inquiring about the technical, curricular and organizational challenges that AR application may be faced with in university education", the obtained results revolve around: the lack of training and improvement of the teaching staff, the few educational experiences that we find ourselves in, the lack of conceptual foundation, the limited educational research 
and the lack of institutional support. That is, aspects that may well be common to other ICTs, and that leads us to be able to have references on the reasons why their incorporation into teaching has failed.

Regarding teacher training, our finding coincides with that indicated by other authors (Billinghur: \& Duenser, 2012; Bower et al., 2014; Cabero-Almenara \& García, 2016; Durall et al., 2012). And in this aspect we would like to point out that such training should not be limited to teachers who acquire skills to manage some of the programs used for their management, such as Aurasma or Vuforia, but must be done under the TPACK model postulates (Mishra \& Koehler, 2006), that is, training that allows teachers to acquire technological knowledge about AR, pedagogical knowledge, for its incorporation into educational practice, and knowledge of content, so that it can be exploited in its specific curricular area.

A significant obstacle is the lack of theoretical foundation, a finding that coincides with the contributions made by different authors (Bower et al., 2014; Rasimah et al., 2011), and that has led many technologies to occupy marginal positions within the curriculum, and in this search for references it may be interesting to contemplate the proposals made by Johnson, Smith, Willis, Levine, and Haywood (2011), which highlight that these technologies can be supported by the following learning approaches: constructivist, contextual, based on games and based on the investigation. Recently, Pedraza, Amado, Lasso, and Munévar (2017), proposed a scheme of the different approaches from which the educational use of AR can be seen (Table 6).

Table 6 Application approaches of the RA (Pedraza et al., 2017)

\begin{tabular}{|c|c|c|c|}
\hline Focus & Instrumental & Cognitive & Sistemic \\
\hline The concept from the AR & Tool and resource & $\begin{array}{l}\text { Pedagogical mediation for } \\
\text { learning purposes }\end{array}$ & $\begin{array}{l}\text { Modeling, simulation } \\
\text { and immersion }\end{array}$ \\
\hline Method of assuming AR & Activity & Strategy & Methodology \\
\hline
\end{tabular}

Regarding the lack of institutional support, this can be considered as one of the aspects that has stalled the use and production of audiovisual and multimedia resources by teachers (Cabero-Almenara et al., 2010) and in this aspect the experience made from the "Secretariat of Audiovisual Resources and New Technologies of the University of Seville" should be noted, which has facilitated through the realization of calls among the university community the production of a variety of AR resources that are in public access ${ }^{3}$.

It has been significant to find that the obstacles indicated by the experts have focused, neither on the student, nor on the difficulty of using this technology, nor on its inefficiency as a didactic resource, but as we have seen in aspects of the teacher, educational practice, and little flexibility of the curriculum.

Referring to negative attitudes, the finding found that this coincides with the diversity of research (Cabero, García, \& Arroyo, 2016; Fonseca et al., 2016; Han et al., 2015; Y. Hsu et al., 2017; Joo et al., 2017; Pérez-López, 2015; Rodríguez, Naranjo, \& Duque, 2016), who have clearly indicated that the students' attitudes towards the obstacles and their degree of

${ }^{3}$ http://ra.sav.us.es/ 
acceptance are very significant.

From a practical point of view, it is advisable that institutions, before facilitating their incorporation into teaching, make decisions regarding the training of teachers and the creation of centers that help teachers to produce these objects of learning. At the same time, measures must be taken to facilitate connectivity in the institutions.

Another of the conclusions shown in the study is the construction of a valid and reliable instrument (AR obstacle questionnaire -CORA-), with a very high reliability index 0.94 (Dwyer \& Bernauer, 2014) and constituted by four blocks (characterization of the expert, questions for the analysis of expert competence, assessment of the influence of a series of obstacles by the experts and open questions for the inclusion of other obstacles not previously indicated), which contained the 13 dimensions obtained from the study result Dephi performed once the coefficient $\mathrm{K}$ Coefficient $\mathrm{K}$ " $\left(\mathrm{K}=\frac{1}{2} \mathrm{Kc}\right.$ (knowledge coefficient) $+\mathrm{Ka}$ (argumentation coefficient)) has been applied.

\section{ACKNOWLEDGEMENTS}

Funded by: Ministry of Economy and Competitiveness of Spain, Spain.

Funder Identifier: http://dx.doi.org/10.13039/501100003329

Award:

Research Project: Augmented Reality to Increase Training. Design, Production, and Evaluation of Augmented Reality Programs for University Education (RAFODIUN).

\section{REFERENCES}

Akçayır, M., \& Akçayır, G. (2017). Advantages and challenges associated with augmented reality for education: A systematic review of the literature. Educational Research Review, 20, 1-11. https://doi.org/10.1016/j.edurev.2016.11.002

Alkhattabi, M. (2017). Augmented Reality as E-learning Tool in Primary Schools' Education: Barriers to Teachers'. Adoption. International Journal of Emerging Technologies in Learning, 12(2), 91-100. https://doi.org/10.3991/ijet.v12i02.6158

Bacca, J., Baldiris, S., Fabregat, R., Graf, S., \& Kinshuk, G. (2014). Augmented Reality Trends in Education: A Systematic Review of Research and Applications. Educational Technology y Society, 17(4), 133-149.

Barroso, J., Cabero, J., \& Llorente, M. C. (2015). El diseño, la producción y la evaluación de TIC aplicadas a los procesos de enseñanza y aprendizaje. In J. Cabero, J. Barroso, et al. (Eds.), Nuevos retos en tecnología educativa (pp. 69-95). Madrid: Síntesis.

Barroso, J., \& Cabero-Almenara, J. (2016). Evaluación de objetos de aprendizaje en Realidad Aumentada: Estudio piloto en el Grado de Medicina. Enseñanza \& Teaching, 34(2), 149-167. https://doi.org/10.14201/et2016342149167

Billinghurst, M., \& Duenser, A. (2012). Augmented reality in the classroom. Computer, 45, 56-63.

Blasco, J., Padrón, A. L., \& Mengual, S. (2010). Validación mediante el método Delphi de un cuestionario para conocer las experiencias e interés hacia las actividades acuáticas con especial atención al windsurf. Ágora para la educación física y el deporte. , 12(1), 75-94. 
Bower, M., Howe, C., McCredie, N., Robinson, A., \& Grover, D. (2014). Augmented reality in education-cases, places and potentials. Educational Media International, 51(1), 1-15. https:// doi.org/10.1080/09523987.2014.889400

Cabero, J., \& Barroso, J. (2013). La utilización del juicio de experto para la evaluación de TIC: el coeficiente de competencia experta. Bordón, 65(2), 25-38. https://doi.org/10.13042/brp.2013 .65202

Cabero, J., García, F., \& Arroyo, C. (2016). La producción de objetos de aprendizaje en realidad aumentada para la formación universitaria en el SAV de la Universidad de Sevilla. In L. Villalustre, M. D. Moral, et al. (Eds.), Experiencias interactivas con realidad aumentada en las aulas (pp. 19-30). Barcelona: Octaedro.

Cabero-Almenara, J., Fernández, B., \& Marín, V. (2017). Dispositivos móviles y realidad aumentada en el aprendizaje del alumnado universitario. Revista Iberoamericana de Educación a Distancia, 20(2), 167-185. https://doi.org/10.5944/ried.20.2.17245

Cabero-Almenara, J., \& García, F. (2016). Realidad Aumentada. Tecnología para la formación. Madrid: Síntesis.

Cabero-Almenara, J., Lozano, J. M., Barroso, J., fernández, J. M., Romero, R., Román, P., ... Ballesteros, C. (2010). Análisis de centros de recursos de producción de las TIC de las universidades españolas. Revista de Educación, 351, 237-257.

Carracedo, J. D. P., \& Méndez, C. L. M. (2012). Realidad Aumentada: Una Alternativa Metodológica en la Educación Primaria Nicaragüense. IEEE-RITA, 7, 102-108.

Chen, C. M., \& Tsai, Y. (2012). Interactive augmented reality system for enhancing library instruction in elementary schools. Computers \& Education, 59, 638-652. https://doi.org/10.1016/ j.compedu.2012.03.001

Cheng, K.-H. (2017). Reading an augmented reality book: An exploration of learners' cognitive load, motivation, and attitudes. Australasian Journal of Educational Technology, 33(4), 53-69. https://doi.org/10.14742/ajet.2820

Coimbra, M., Cardoso, T., \& Mateus, A. (2015). Augmented Reality: an Enhancer for Higher Education Students in Math's learning? Procedia Computer Science, 67, 332-339. https:// doi.org/10.1016/j.procs.2015.09.277

Cuendet, S., Bonnand, Q., Do-Lenh, S., \& Dillenbourg, P. (2013). Designing augmented reality for the classroom. Computers \& Education, 68, 557-569. ttps://doi.org/10.1016/j.compedu.2013 .02 .015

Dunleavy, M., Dede, C., \& Mitchell, R. (2010). Affordances and limitations of immersive participatory augmented reality simulations for teaching and learning. Journal of Science Education and Technology, 18(1), 7-22. https://doi.org/10.1007/s10956-008-9119-1

Durall, E., Gros, B., Maina, M., Johnson, L., \& Adams, S. (2012). Perspectivas tecnológicas: educación superior en Iberoamérica 2012-2017. Austin, Texas: The New Media Consotium.

Dwyer, L. O., \& Bernauer, J. (2014). Quantitative research for the qualitative researcher. California: Sage.

Escobar, J., \& Cuervo, A. (2008). Validez de contenido y juicio de experto: una aproximación a su utilización. Avance en Medicina, 6, 27-36.

Fombona, J., Pascual, M. J., \& Madeira, M. F. (2012). Realidad aumentada, una evolución de las aplicaciones de los dispositivos móviles. Píxel-Bit. Revista de Medios y Educación, 41, 197210.

Fonseca, D., Redondo, E., \& Valls, F. (2016). Motivación y mejora académica utilizando realidad aumentada para el estudio de modelos tridimensionales arquitectónicos. Education in the Knowledge Society, EKS, 17(1), 45-64. https://doi.org/10.14201/eks20161714564

Fracchia, C., Alonso, A., \& Martins, A. (2015). Realidad Aumentada aplicada a la enseñanza de 
Ciencias Naturales. Revista Iberoamericana de Educación en Tecnología y Tecnología en Educación, 16, 7-15.

Garay, U., Tejada, E., \& Maiz, I. (2017). Valoración de objetos educativos enriquecidos con realidad aumentada: una experiencia con alumnado de máster universitario. Pixel-Bit. Revista de Medios y Educación, 50, 19-31. https://doi.org/10.12795/pixelbit.2017.i50.01

García, L., \& Fernández, S. (2008). Procedimiento de aplicación del trabajo creativo en grupo de expertos. Energética, XXIX, 2, 46-50.

Gil-Gómez, B., \& Pascual-Ezama, D. (2012). La metodología Delphi como técnica de estudio de la validez de contenido. Anales de psicología, 28(3), 1011-1020. https://doi.org/10.6018/analesps .28.3.156211

Han, J., Jo, M., Hyun, E., \& So, H. (2015). Examining young children's perception toward augmented reality-infused dramatic play. Education Technology Research Development, 63, 455474. https://doi.org/10.1007/s11423-015-9374-9

Hernández, R., Fernández, C., \& Baptista, M. P. (2010). Metodología de la investigación. México D.F.: McGraw-Hill.

Hsu, J. L., \& Huang, Y. H. (2011). The Advent of Augmented-Learning: A Combination of Augmented Reality and Cloud Computing. In C. Ho \& M. Lin (Eds.), Proceedings of E-Learn: World Conference on E-Learning in Corporate, Government, Healthcare, and Higher Education (pp. 1328-1333). Chesapeake, VA: ssociation for the Advancement of Computing in Education (AACE).

Hsu, T. C. (2017). Learning English with Augmented Reality: Do learning styles matter? Computers \& Education, 106, 137-149. https://doi.org/10.1016/j.compedu.2016.12.007

Hsu, Y., Lin, Y., \& Yang, B. (2017). Impact of augmented reality lessons on students' STEM interest. Research and Practice in Technology Enhanced Learning, 12(2), 1-14. https://doi.org/10.1186/ s41039-016-0039-Z

Ibáñez, M., \& Delgado-Kloos, C. (2018). Augmented reality for STEM learning: A systematic review. Computer \& Education, 123, 109-123. https://doi.org/10.1016/j.compedu.2018.05.002

Jamali, S., Fairuz, M. W., undefined K., \& Oskam, C. (2015). Utilising mobile-augmented reality for learning human anatomy. Procedia-Social and Behavioral Sciences, 197, 659-668. https:// doi.org/10.1016/j.sbspro.2015.07.054

Johnson, L., Adams, S., \& Cummins, M. (2012). NMC Horizon Report: 2012 K-12 Edition. Austin, Texas: NMC Horizon Report.

Johnson, L., Smith, R., Willis, H., Levine, A., \& Haywood, K. (2011). The 2011 Horizon Report. Austin, Texas: The New Media Consortium.

Joo, J., García-Bermejo, J., \& Martinez-Abad, F. (2016). Virtual Heritage of the Territory: Design and Implementation of Educational Resources in Augmented Reality and Mobile Pedestrian Navigation. IEEE Revista Iberoamericana de Tecnologias del Aprendizaje, 11(1), 41-46.

Joo, J., Martínez, F., \& García-Bermejo, J. R. (2017). Realidad Aumentada y Navegación Peatonal Móvil con contenidos Patrimoniales: Percepción del aprendizaje. RIED. Revista Iberoamericana de Educación a Distancia, 20(2), 93-118. https://doi.org/10.5944/ried.20.2.17602

Lagunes-Domínguez, A., Torres-Gastelú, C., Angulo-Armenta, J., \& Martínez-Olea, M. (2017). Prospectiva hacia el Aprendizaje Móvil en Estudiantes Universitarios. Formación universitaria, 10(1), 101-108. https://doi.org/10.4067/S0718-50062017000100011

Lin, J., Bim-Lirn, H., Li, N., Wang, H., \& Tsai, C. (2013). An Investigation of Learners' Collaborative Knowledge Construction Performances and Behavior Patterns in an Augmented Reality Simulation System. Computers \& Education, 68, 314-321. https://doi.org/10.1016/ j.compedu.2013.05.011

Liu, P., \& Tsai, M. (2013). Using augmented-reality-based mobile learning material in EFL English 
composition: An exploratory case study. British Journal of Educational Technology, 44(1), 1-4. https://doi.org/10.1111/j.1467-8535.2012.01302.x

Llorente, M., \& Journal of New Approaches in Educational Research. (2013). Assessing Personal Learning Environments (PLEs). An expert evaluation. , 2(1), 39-44. https://doi.org/10.7821/ naer.2.1.39-44

López-Gómez, E. (2018). El método Delphi en la investigación actual en educación: una revisión teórica y metodológica. Educación XXI, 21(1), 17-40. https://doi.org/10.5944/educxx1.20169

Lu, S., \& Liu, Y.-C. (2015). Integrating augmented reality technology to enhance children's learning in marine education. Environmental Education Research, 21(4), 525-541. https://doi.org/ 10.1080/13504622.2014.911247

Maquilón, J. J., Mirete, A., \& Avilés, M. (2017). La Realidad Aumentada (RA). Recursos y propuestas para la innovación educativa. Revista Interuniversitaria de Formación del Profesorado, 20(2), 183-203. https://doi.org/10.6018/reifop/20.2.290971

Martínez, S., \& Fernández, B. (2018). Objetos de realidad aumentada: percepciones del alumnado de pedagogía. Pixel-Bit. Revista de Medios y educación, 53, 207-220. https://doi.org/10.12795/ pixelbit.2018.i53.14

Mengual-Andrés, S., Roig-Vila, R., \& Blasco, J. (2016). Delphi study for the design and validation of a questionnaire about digital competences in higher education. International Journal of Educational Technology in Higher Education, 13(12). https://doi.org/10.1186/s41239-016-0009-y

Mishra, P., \& Koehler, M. (2006). Technological pedagogical content knowledge: A framework for teacher knowledge. The Teachers College Record, 108(6), 1017-1054. https://doi.org/10.1111/ j.1467-9620.2006.00684.x

Odeh, S., Shanab, S., \& Anabtawi, M. (2015). Augmented Reality Internet Labs versus its Traditional and Virtual Equivalence. International Journal Of Emerging Technologies In Learning (IJET), 10(3), 4-9. https://doi.org/10.3991/ijet.v10i3.4354

O'Shea, P., Folkestad, J., \& Proceedings of EdMedia: World Conference on Educational Media and Technology. (2012). An Analysis of Engagement in a Combination Indoor/Outdoor Augmented Reality Educational Game. In T. Amiel \& B. Wilson (Eds.), (pp. 1127-1147). Association for the Advancement of Computing in Education (AACE).

Pedraza, C., Amado, O., Lasso, E., \& Munévar, P. (2017). La experiencia de la realidad aumentada (RA) en la formación del profesorado en la universidad nacional abierta y a distancia UNADColombia. Pixel-Bit. Revista de Medios y Educación, 51, 111-131. https://doi.org/10.12795/ pixelbit.2017.i51.08

Pérez-López, D. (2015). eJUNIOR: Sistema de Realidad Aumentada para el conocimiento del medio marino en educación primaria. Quid, 24, 35-42.

Pérez-Pérez, M., Gómez, E., \& Sebastián, M. (2018). Delphi Prospection on Additive Manufacturing in 2030: Implications for Education and Employment in Spain. Materials, 11(9). https:// doi.org/10.3390/ma11091500

Radu, I. (2014). Augmented reality in education: a meta-review and cross-media analysis. Personal and Ubiquitous Computing, 18(6), 1-11. https://doi.org/10.1007/s00779-013-0747-y

Rasimah, C., Ahmad, A., \& Zaman, H. (2011). Evaluation of user acceptance of mixed reality technology. Australasian Journal of Educational Technology, 27, 1369-1387. https://doi.org/ 10.14742/ajet.899

Rodríguez, A., Naranjo, M., \& Duque, N. (2016). Prueba de usabilidad y satisfacción en objetos de aprendizaje con Realidad Aumentada en aplicaciones móviles. In S. Baldiris (Ed.), Recursos Educativos Aumentados Una oportunidad para la inclusión (pp. 55-65). Colombia: Sello Editorial Tecnolkógico Comfenalco.

Saidin, N., Halim, N. A., \& Yahaya, N. (2015). A Review of Research on Augmented Reality in 
Education: Advantages and Applications. International Education Studies, 8(13), 1-8. https:// doi.org/10.5539/ies.v8n13p1

Santos, M., Wolde, A., Taketomi, T., Yamamoto, G., Rodrigo, M., Sandor, C., \& Kato, H. (2016). Augmented reality as multimedia: the case for situated vocabulary learning. Research and Practice in Techology Enhanced Learning, 11(4), 1-23. https://doi.org/10.1186/s41039-016 $-0028-2$

Seifert, T., Hervás, C., \& Toledo, P. (2019). Diseño y validación del cuestionario sobre percepciones y actitudes hacia el aprendizaje por dispositivos móviles. Pixel-Bit. Revista de Medios y Educación, 54, 45-64. https://doi.org/10.12795/pixelbit.2019.i54.03

Serio, A. D., Ibáñez, M. B., \& Delgado, C. (2013). Impact of an augmented reality system on students' motivation for a visual art course. Computers y Education, 68, 586-596. https://doi.org/10 .1016/j.compedu.2012.03.002

Tekedere, H., \& Göker, H. (2016). Examining the Effectiveness of Augmented Reality Applications in Education: A Meta-Analysis. International Journal of Environmental \& Science Education, 11(16), 9469-9481.

Telefónica, F. (2011). Realidad Aumentada: una nueva lente para ver el mundo. Madrid: Fundación Telefónica-Ariel.

Tsai, M., Liu, P., \& Yau, J. (2013). Using electronic maps and augmented reality-based training materials as escape guidelines for nuclear accidents: An explorative case study in Taiwan. British Journal of Educational Technology, 44(1), E18-E21. https://doi.org/10.1111/ j.1467-8535.2012.01325.x

Wang, X., Jeong, M., Love, P., \& Kang, S.-C. (2013). Augmented Reality in built environment: Classification and implications for future research. Automation in Construction, 32, 1-13. https://doi.org/10.1016/j.autcon.2012.11.021

Wang, Y. (2017). Using augmented reality to support a software editing course for college students. Journal of Computer Assisted Learning, 33, 532-546. https://doi.org/10.1111/jcal.12199

Wojciechowski, R., \& Cellary, W. (2013). Evaluation of learners' attitude toward learning in ARIES augmented reality environments. Computers \& Education, 68, 570-585. https://doi.org/10 .1016/j.compedu.2013.02.014

Wu, H.-S., Wen-Yu, S., Chang, H.-Y., \& Liang, J. (2013). Current status, opportunities and challenges of augmented reality in education. Computers \& Education, 62, 41-49. https://doi.org/10 .1016/j.compedu.2012.10.024

Yilmaz, R. M., \& Goktas, Y. (2017). Using augmented reality technology in storytelling activities: examining elementary students' narrative skill and creativity. Virtual Reality, 21(2), 75-89. https://doi.org/10.1007/s10055-016-0300-1

Zartha, J., Montes, J., Toro, I., \& Villada, H. (2014). Método Delphi - Propuesta para el cálculo del número de expertos en un estudio Delphi sobre empaques biodegradables al 2032. Espacios, 35(13). 